\title{
First report of fruit rot of eggplant caused by Pythium viniferum in Turkey
}

\author{
Şahimerdan Türkölmez ${ }^{1}$. Göksel Özer ${ }^{2} \cdot$ Osman Çiftçi $^{3} \cdot$ Sibel Dervişs ${ }^{4}(1)$
}

Received: 15 June 2020 / Accepted: 1 October 2021 / Published online: 15 October 2021

(c) Società Italiana di Patologia Vegetale (S.I.Pa.V.) 2021

Keywords Solanum melongena $\cdot$ Pythium viniferum $\cdot$ Fruit rot

In August 2019, symptoms including dark brown and irregular sunken lesions or blights on the fruit pedicel and calyx of eggplants (Solanum melongena L.) occurred with a 3\% incidence in two fields in Şanluurfa province of Turkey. Advanced symptoms caused complete rotting of the fruit and visible cottony mycelia on the surface of pedicel, calyx, and fruit. To identify the causal agent, isolation was conducted with potato carrot agar (PCA). After an incubation period at $20^{\circ} \mathrm{C}$ for $72 \mathrm{~h}$ in the dark, isolates obtained were mainly resembling the morphology of Pythium species according to the key of Van der Plaats-Niterink (1981). Sporangia were in an intercalary or terminal position, spherical to elongated, measured between $8-16 \mu \mathrm{m}$ in diameter (mean $12.3 \mu \mathrm{m})$, and plentifully produced on aseptate hyphae. Spherical oospores were usually plerotic and measured 13.6 to $20.7 \mu \mathrm{m}$ (mean $16.5 \mu \mathrm{m}$ ). No zoospores were observed. These morphological characteristics were consistent with those of Pythium viniferum B. Paul (Paul et al. 2008). The internal transcribed spacer (ITS) regions and the large subunit (LSU) of rDNA of representative isolates were sequenced with the primer pairs ITS1/ ITS4 and NL1/NL4 and deposited in GenBank under accession numbers MT251151-52 and MT251135-36, respectively. The resultant sequences had $100 \%$ similarity with the sequences of P. viniferum, KX788835 and HQ643956, respectively. For the pathogenicity assay, 7-mm diameter mycelial plugs excised from seven-day-old colonies were deposited on 15 fruits wounded

Sibel Derviş

sibeldervis@gmail.com

1 GAP Agricultural Research Institute, Şanlıurfa 63040, Turkey

2 Faculty of Agriculture, Department of Plant Protection, Bolu Abant Izzet Baysal University, Bolu 14020, Turkey

3 Diyarbakır Plant Protection Research Station, 21110 Yeniş̧ehir, Diyarbakır, Turkey

4 Department of Plant and Animal Production, Mardin Artuklu University, Vocational School of Kiz1ltepe, Mardin 47000, Turkey with a sterile needle. Sterile agar plugs were applied to wounded control fruits. After incubation in a humidity chamber at $20^{\circ} \mathrm{C}$ for seven days, inoculated fruits exhibited symptoms similar to those recorded in the field, while no symptoms were observed on the control fruits. The pathogen was re-isolated and identified to fulfill Koch's postulates. In North Dakota, the same oomycete has been reported to cause damping-off on soybean seedlings (Zitnick-Anderson and Nelson 2015). To our knowledge, this is the first report of fruit rot of eggplant caused by $P$. viniferum in Turkey and worldwide (Farr and Rossman 2020).

\section{Declarations}

Research involving human participants and/or animals The authors declare that no human participants and animals were involved in this study.

Informed consent This manuscript is new and not being considered elsewhere. All authors have approved the submission of this manuscript.

Conflict of interest The authors declare that they have no conflict of interest.

\section{References}

Farr DF, Rossman AY (2020) Fungal Databases, U.S. National Fungus Collections, ARS, USDA. https://nt.ars-grin.gov/fungaldatabases/. Accessed 15 Jun 2020

Paul B, Mathew R, Kanak B, Paul A, Henry M, Lefort F, Belbahri L (2008) Morphology, taxonomy, and phylogenetic analysis of a new species of Pythium isolated from France. Fungal Divers 28:55-63

Van der Plaats-Niterink AJ (1981) Monograph of the genus Pythium. Stud Mycol 21:1-239

Zitnick-Anderson KK, Nelson BD Jr (2015) Identification and pathogenicity of Pythium on soybean in North Dakota. Plant Dis 99:31-38

Publisher's Note Springer Nature remains neutral with regard to jurisdictional claims in published maps and institutional affiliations. 